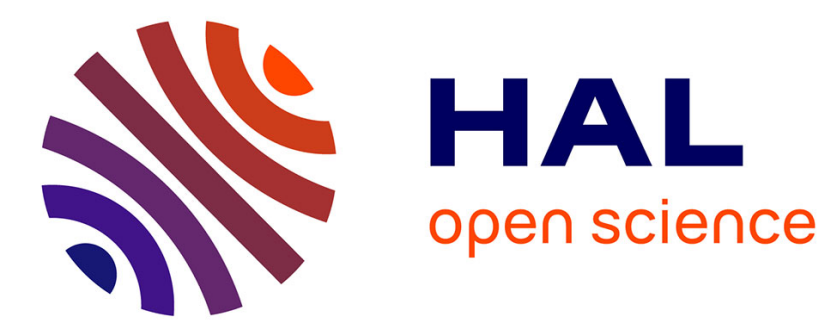

\title{
Methods for distributing results in exploratory partnerships
}

Elodie Gardet, Pierre-Laurent Felix

\section{To cite this version:}

Elodie Gardet, Pierre-Laurent Felix. Methods for distributing results in exploratory partnerships. Technology Analysis and Strategic Management, 2013, 25 (4), pp.445-458. 10.1080/09537325.2013.774345 . hal-01287002

\section{HAL Id: hal-01287002 \\ https://hal.science/hal-01287002}

Submitted on 11 Mar 2016

HAL is a multi-disciplinary open access archive for the deposit and dissemination of scientific research documents, whether they are published or not. The documents may come from teaching and research institutions in France or abroad, or from public or private research centers.
L'archive ouverte pluridisciplinaire HAL, est destinée au dépôt et à la diffusion de documents scientifiques de niveau recherche, publiés ou non, émanant des établissements d'enseignement et de recherche français ou étrangers, des laboratoires publics ou privés. 


\title{
Methods for distributing results in exploratory partnerships
}

\author{
Elodie Gardet, IREGE, Université de Savoie \\ Pierre Laurent FELIX, INSEEC
}

\begin{abstract}
Development partnerships enable companies to develop new products and/or processes while sharing costs. In addition to uncertainty and increased risk, these partnerships necessitate adapted management techniques. In particular, partners must determine the distribution of results and methods of distribution. This article describes different results in development partnerships according to their methods of distribution. A qualitative study of three exploratory projects, developed in the MINATEC IDEAs Laboratory®, offers a better understanding of the chosen methods and influential factors. Before the collaboration, partners preferred egalitarian divisions, because it was difficult to identify the resources and skills necessary in the project. However, this method of distribution provided less incentive than an equitable distribution. The structural dimensions (number of partners, degree of partnership maturity, similarity with core professions) and partners' behaviours (level of implication, interest in the project) also influenced the method of distribution implemented.
\end{abstract}

Keywords: Exploratory partnership, distribution of results, innovation 
In organisational relationships, partners often cannot accurately forecast the risks inherent to alliances, particularly in exploratory partnerships that are, by their very nature, uncertain (Gillier et al., 2010). Prior to the project start, the partners cannot foresee the likely risks, difficulties and outcomes. In turn, it is difficult to define ex ante how to distribute the results (Jap 2001), though this distribution decision is essential for encouraging partners to collaborate. The rules for sharing responsibilities, resources and quasi-rents must be defined to encourage members to transfer key knowledge to the project and maximise chances of success. This incentive requires a prior definition of the general rules for sharing output, which further ensures the protection of each party's contributions. Yet research rarely details these rules regarding sharing, or else reviews them in only summary fashion (Bhaskaran and Krishnan 2009).

Prior research suggests two main distributions though: egalitarian (i.e., each partner obtains an equivalent result) or equitable (i.e., the distribution is proportional to the resources and skills contributed by each partner). To choose between them, partners must identify the influential dimensions; accordingly, this article aims to analyse the situations in which it is preferable to use egalitarian versus equitable distribution. We begin with a summary of prior literature on the specificities of exploratory partnerships, the types of results that can be produced and possible methods for distributing these outputs. Then we present three exploratory innovation projects, developed in partnerships in the MINATEC IDEAs Laboratory, and outline the data we collected to analyse them. The results address the methods of distribution adopted by the partners in these projects, as well as the dimensions that influenced these choices.

\section{From exploration to distribution methods}

An exploratory partnership is a particular form of R\&D collaboration, which possesses specific significance for the study of result distributions, as well as unique incentives. 


\section{Specificities of an exploration partnership}

In the past 15 years, various new forms of collaboration between companies have arisen (Doz and Hamel 1998), as evidenced by the number of hybrid forms (e.g. alliances, consortiums, joint ventures, agreements). For this study, we define collaboration as 'a situation in which two organisations or more share resources and activities in order to follow a strategy' (Johnson et al., 2008, p. 461), designed to respond to or anticipate the needs and evolutions of a market. They also can be motivated by a wish to share risks and costs to develop a new product. This means of development appears well adapted to innovation.

New models of open innovation (Chesbrough 2003) encourage companies to undertake some R\&D in partnership with others, which produce new organisational forms: research consortiums, co-development projects, joint ventures and exploration partnerships (Gillier et al., 2010). In particular, an exploration partnership involves companies undertaking innovation by pursuing 'investigation activity and recognition of new fields of action, or more specifically, "fields of innovation"” (Segrestin 2006, p. 6). The partners simultaneously assess technical possibilities and value spaces (Le Masson, Weil, and Hatchuel 2006). Thus exploration partnerships go beyond the simple co-development of an innovative product or service. Exploration activity implies that partners lack a concrete idea of what the final result of the collaboration will be. Along the way, they construct the object of their collaboration, or their common purpose (Gillier et al., 2010). Exploration therefore differs from systems of conception in which identified experts define specifications using known characteristics of the product or service. Instead, there is considerable, inherent uncertainty in exploration.

The exploratory partnership also can take different forms, according to its structure (see Table 1), such as an alliance (or joint venture), consortium or project team hosted by one partner. However, the type of structure determines the mechanisms for coordination and 
control (Segrestin 2006), such that the choice of partner is crucial (Emden, Calantone, and Droge 2006; Todeva and Knoke 2005; Kang and Kang 2010). Is it preferable to choose complementary partners or radically different ones (in terms of skills, markets)? For Bierly and Gallagher (2007), partner selection should reflect the resources and skills needed for the collaboration. Nooteboom et al. (2007) instead suggest the partners should have some form of compatibility, which depends on their degree of similarity. If partners are greatly alike (e.g. equivalent financial resources, skills, similar managerial practices), the alliance has significant action potential but limited exploratory potential (Kang and Kang 2010). Conversely, if the partners are radically different, their cognitive distance causes difficulties in understanding, which can undermine the management of the alliance but favour exploration.

Table 1. Legal forms and contractual arrangements in exploration partnerships

\begin{tabular}{|c|c|c|c|c|}
\hline & Joint Venture & PLC & Partnership & $\begin{array}{c}\text { Collaboration } \\
\text { Agreement }\end{array}$ \\
\hline Control & Joint & Key person & Key person & Co-governance \\
\hline Decision Power & $\begin{array}{l}\text { Multiple voting } \\
\text { rights }\end{array}$ & $\begin{array}{c}\text { Voting rights } \\
\text { proportional to } \\
\text { shares }\end{array}$ & Unanimity & $\begin{array}{l}\text { Multiple } \\
\text { voting rights }\end{array}$ \\
\hline $\begin{array}{c}\text { Result } \\
\text { Distribution } \\
\text { Method }\end{array}$ & $\begin{array}{c}\text { Proportion of the } \\
\text { shares }\end{array}$ & $\begin{array}{l}\text { Proportion of } \\
\text { the shares }\end{array}$ & $\begin{array}{c}\text { Propertion of the } \\
\text { shares }\end{array}$ & $\begin{array}{l}\text { Defined a } \\
\text { priori }\end{array}$ \\
\hline
\end{tabular}

Notes: Adapted from Segrestin (2006, p. 133).

Furthermore, a central characteristic of an exploratory partnership is its intrinsic instability, in connection with its exploration activity. This characteristic causes tensions and may make result distribution methods more complex. The intrinsic instability of an exploratory partnership relates to its flexibility, because to respond to technological and commercial uncertainties, an exploratory partnership must adapt to its environment. The resulting innovation is a key sustainable competitive advantage (Nelson and Winter 1982), though researchers still question the best way to develop such competitive advantages. 
Various works confirm the importance of organisational variables (Griffin and Page 1993; Yap and Souder 1994; Malik and Wei 2011), with increasing attention devoted to the internal functioning of alliances (Dhanaraj and Parkhe 2006; Rothaermel and Deeds 2004).

Exploratory partnerships may improve the chances of success for innovative projects, because they enable risk sharing and exchanges of information and know-how (Gillier et al., 2010). They also encourage training and are more conductive to innovation than are individual companies (Powell, Koput, and Smith-Doerr 1996). As a strategic tool, an exploratory partnership offers a solution that partners can use to acquire new skills or develop new technology quickly. To these ends, different partners share project risks to greater or lesser extents, using the different tactics available to them and exchanging resources and skills (Goes and Park 1997; Powell 1987). Other potential advantages include increased profits, greater client satisfaction and reduced development time, which implies lower costs as well. Despite these benefits, some research implies that they cannot guarantee success (Karlsson 1997), especially when the inherent tension of collaboration produces high functional and collaboration costs that endanger innovation activity (Cooper 1999). In this setting, the distribution of results could be an important means to minimise these risks (Jap 2001; Leiblein and Madsen 2009).

The high level of uncertainty and increased risk associated with the specificities of exploratory partnerships create questions about the best methods for distributing results between partners. Despite the difficulties associated with choosing these methods from the outset, this choice appears absolutely essential to encourage partners to collaborate (Segrestin 2006).

\section{Incentives through distribution}

The outcomes of an exploration partnership can vary in nature and be subject to bimodal distribution. For example, the decision to undertake a collective exploratory project 
implies a strategic logic that pursues a portfolio of real options (McMillan and McGrath 2000). Real options refer to 'limited investments that generate several opportunities for future development' (Johnson et al. 2008, p. 407), and they consist of three types: positioning options, springboard options and exploration options characterised by their degrees of technical and market uncertainty (see Figure 1).

\section{Figure 1. Categorisation of development options}

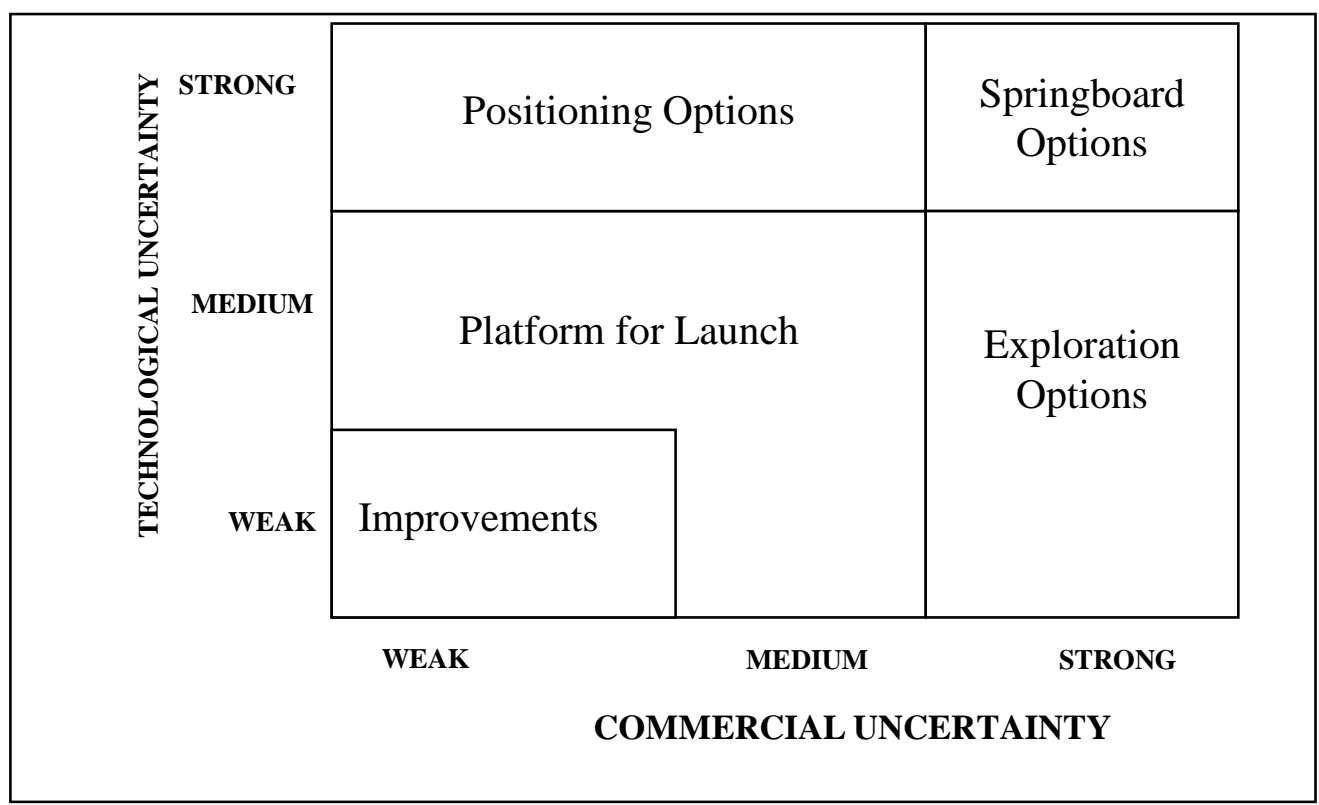

Notes: Adapted from McMillan and McGrath (2000, p. 176).

For this study, exploration options correspond to the exploration logic of Segrestin (2006): experiments whose main objective is to define innovative concepts, even without knowledge of the market or technology in advance. They represent entrepreneurial experiments that aim to discover and/or create new markets for products and services by using abilities obtained in other fields of investigation (McMillan and McGrath 2000). By choosing an exploration option, the company commits to launching an innovative project in a dedicated, independent structure, such that it is not subject to the constraints of internal development, which matches the research assertion that 'Exploring innovative opportunities 
by creating an external entity such as a partnership is highly recommended ... (Bower and Christensen, 1995; Foss, 2003)’'(Gillier et al., 2010, p. 885).

In turn, its exploratory activities enable the company to develop new skills, register new patents, construct models and tackle new concepts, such that their 'form of innovation ... moves away from the company's existing central skills based on clients or technology' (Chanal and Mothe 2005, p. 5). Because exploration entails more than an attempt to produce an innovation that answers needs, the related activity generates learning and leads to the development of new skills, depending on the explorer's preceding career path, knowledge of instruments and existing skills (Gillier et al., 2010).

Then the results of this exploration activity (whether financial or not) must be distributed, which provides an essential motivating factor (Sakakibara 1997). However, little research proposes appropriate solutions for such distribution (Catelin 2002;Kumar and Nti 1998). According to sparse literature on distribution sharing (Jap, 2001; Kabanoff 1991), two sharing principles are most common: equity and equality. The complex distribution of results (Blanchot 2006) should depend on norms of justice, which vary across groups and cultures. Equity is not universally considered superior to equality, though 'in collaborative relations where economic productivity is the first objective, equity rather than equality tends to be the principle directive force in distributive justice... With the aim of encouraging and rewarding the contributions of those who are most capable, results are distributed according to the inputs' (Kabanoff 1991, p. 417). An equitable distribution of results, chosen prior to the collaboration, should encourage members of the partnership to exert effort and perhaps enhance success likelihoods (Jap 2001; Kabanoff 1991). The ratio of distribution may reflect decision makers' perceptions of the members of the team (Adams 1963), often based on elements such as: 
- Sharing of tasks (Arino and De La Torre 1998; Inkpen and Beamish 1997; Kogut 1989; Larsson et al. 1998).

- Sharing of information (Borys and Jemison 1989; Mohr and Spekman 1994).

- Commitment (Anderson and Weitz 1992).

If a distribution seems inequitable to members, the alliance results are affected (Kumar and Nti 1998). If members perceive they are being treated unequally, the level of commitment by the disadvantaged partner diminishes. Systems based on equitable distribution also encourage competition among members and risk taking to increase profits. The resulting rivalry can paralyse collaboration. Jap (2001) asserts that the ability to separate each organization's input to the partnership and the joint creation of idiosyncratic input improves relationship quality in general. But the use of more complex sharing principles, such as the equity principle, when the parties have an understanding of each other's transformation process, has a negative impact on relationship quality. He therefore suggests that the use of an equity principle when an organization can map a reasonable expectation of the payoff ex ante may be excessive. For these reasons, equitable distribution is preferable only in certain cases.

An egalitarian distribution instead implies uniformity and a lack of differentiation of the members of the partnership. Different members obtain an equivalent share of the results, regardless of the resources and skills they contribute (i.e. equal shares, independent of investment) (Jap 2001). The possible injustice created by this distribution represents a significant risk that even might alter the functioning of the partnership. However, this system offers the advantage of encouraging more collaborative, non-competitive behaviour (Brickley, Smith, and Zimmerman 1997).

Table 1. Comparison of two distributions

\begin{tabular}{|c|c|c|}
\hline & Equitable Distribution & Egalitarian Distribution \\
\hline Definition & $\begin{array}{l}\text { Each partner's outcomes are a } \\
\text { function of its resource } \\
\text { contributions (tangible and } \\
\text { intangible) to the exploratory }\end{array}$ & $\begin{array}{l}\text { Each partner receives an equal } \\
\text { share of the outcomes. It is a } \\
50 / 50 \text { split }\end{array}$ \\
\hline
\end{tabular}




\begin{tabular}{|c|c|c|}
\hline & partnership & \\
\hline \multirow[b]{2}{*}{$\begin{array}{c}\text { Main } \\
\text { advantages }\end{array}$} & $\begin{array}{l}\text { Efficient when the partners offer } \\
\text { high financial or technical } \\
\text { contributions }\end{array}$ & $\begin{array}{l}\text { - Easy to implement, especially } \\
\text { when there are various, hard-to- } \\
\text { measure resources }\end{array}$ \\
\hline & $\begin{array}{l}\text { - Advisable when partners } \\
\text { contribute at different levels. }\end{array}$ & 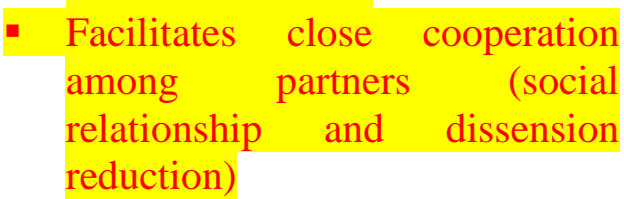 \\
\hline $\begin{array}{c}\text { Main } \\
\text { disadvantages }\end{array}$ & $\begin{array}{l}\text { Evaluation of the assets } \\
\text { contributed by each partner is } \\
\text { quite subjective. } \\
\text { Often favours the larger firm. }\end{array}$ & $\begin{array}{l}\text { Less incentive, because it can } \\
\text { favour opportunistic behaviour } \\
\text { - More difficult to find a 'hub } \\
\text { firm' to manage the project }\end{array}$ \\
\hline
\end{tabular}

In summary, the challenges of both means of distribution suggest it is not possible to retain one instead of the other (see Table 1). Prior literature on distribution methods thus offers some hints about the dimensions that influence this choice, by noting that 'Much attention has been given to how organizations "expand the pie" of benefits between them; however, there is little that addresses the ensuing issue: how organizations divide the expanded pie' (Jap, 2001: 86). In such a situation, an exploratory study can lead to better comprehension of the main characteristics that determine the choice. Accordingly, we conduct an exploratory analysis of several projects that share some common points but also differ enough to reveal dimensions that influence the choice of distribution method.

\section{Three exploration projects from the MINATEC IDEAs Laboratory ${ }^{1}$}

To investigate result distribution methods in the specific context of exploration activity in a collaborative situation, we begin by describing our methodology, then detail the case study we use, which features the MINATEC IDEAs Laboratory and three exploration projects that emerged from it.

\section{Exploratory study}

Because we aim for a better understanding of the methods of distribution in exploration partnerships and the dimensions that influence these choices, we undertook an exploratory case study to investigate key phenomena in context. Case studies can help accomplish various

\footnotetext{
${ }^{1}$ MINATEC IDEAs Laboratory and MINATEC are the names registered by the CEA.
} 
aims: to provide description, test theory or generate theory for example (Eisenhardt, 1989).

Our main aim is to describe and analyse a complex phenomenon that has received insufficient attention. In addition, the case study method can provide more in-depth and rich information about a phenomenon than surveys and quantitative methods do (Yin, 2003), which allows for a careful observation of the focal phenomenon (Eisenhardt, 1989). This approach also offers a more complete view of the various causes of each phenomenon and their potential interactions (Miles and Huberman 2003). Finally, we can adapt this approach to the research context, as needed.

We carried out 20 semi-directive interviews that lasted, on average, one and one-half hours. The interviews, with different members of the exploration partnerships (including those legally responsible for the partnerships, or project leaders) (see Table 2), had the objective of understanding the result distribution methods and the dimensions that influenced the choice of methods. Each interview thus concentrated on partnership characteristics, the collaboration between members and incentive mechanisms implemented, as well as the means used to distribute the results.

All respondents agreed to allow a digital audio recording of the interview. We began by explaining how the interview would be conducted and assuring them of the confidentiality of their remarks. We created a summary and complete transcript of each interview immediately after its completion. To supplement the interview data, we gathered secondary internal data (e.g. meeting minutes, partnership contracts, documents describing innovation projects) and external data (e.g. press releases). Through manual coding of each interview and the secondary data, we derived a dictionary of themes (as described in the next section) that constituted the material for the analysis.

\section{Description of exploratory partnership and three projects}


The MINATEC IDEAs Laboratory is a partnership based in Grenoble, next to the French Center of Research in Micro-nanotechnology (MINATEC). It comprises eight partners: six industrial and two academic members. Since 2003, the partnership also has included several corporate partners that, for strategic reasons, wish to remain anonymous. $\mathrm{A}$ memorandum of understanding (MOU) among CEA Leti, France Telecom, ST Microelectronics and Hewlett Packard, signed in 2001, prefigured the creation of the MINATEC IDEAs Laboratory partnership in Grenoble, France. The partnership was made public in 2003, when its name was registered with the Institut National de la Propriété Industrielle, which changed the set up from a simple multilateral agreement to a detailed eontractual alliance agreement. The MINATEC IDEAs Laboratory defines itself as a "platform whose mission is to imagine new frequently used objects and services based on advances in micro and nanotechnologies' (Table 2). This declared ambition reveals its exploratory nature (i.e. discovering technological fields and new applications), rather than simple technological developments. The stated aim of the partnership is to imagine new frequently used objects and services based on advances in micro and nanotechnologies', so it works with state-of-the-art technology and micro- and nanotechnologies to design, characterise and produce mechanisms and systems that can be controlled on the nanometre scale. Thus MINATEC IDEAs Laboratory can be qualified as an exploratory partnership, because of the nature of its exploration: At the beginning of each project, the partners do not know the outcomes a priori. The only certainty is that the innovation will involve micro- and nanotechnology. The return on investment is measured as new concepts created.

Table 2. Deseriptive summary of MINATEC HDEAs Laboratory partnership (2009) MHNATEC IDEAs Laboratory (

\begin{tabular}{|c|c|}
\hline Statute & Partnership of companies and universities, implying the creation of an ad \\
Hoc structure
\end{tabular}




\begin{tabular}{|c|c|}
\hline Profession & $\begin{array}{c}\text { To imagine, propose and validate by the use of new applications and } \\
\text { objects integrating micro and nanotechnologies }\end{array}$ \\
\hline $\begin{array}{l}\text { Number of } \\
\text { partners }\end{array}$ & 7 partners \\
\hline Size & - 60 individuals \\
\hline $\begin{array}{l}\text { Form-of } \\
\text { authority }\end{array}$ & $\begin{array}{l}\text { Centralised: decisions made by executive authority (management } \\
\text { committee) }\end{array}$ \\
\hline $\begin{array}{l}\text { Division of } \\
\text { work }\end{array}$ & Professional groups \\
\hline
\end{tabular}

In 2009, MINATEC IDEAs Laboratory had seven members: Bouygues, Renault,

EDF, the CEA, Isere County Council and two Grenoble area universities (Pierre Mendès

France: Human and Social Sciences and Stendhal: Literature, Languages and

Communication). Since 2003, the partnership also has included corporate partners such as

Hewlett Packard, Essilor, France Telecom, Rossignol, STMicroelectronics and Teamlog, as

well as others that for strategic reasons wish to remain anonymous.

The current partners have varying characteristics, so the MINATEC IDEAs

Laboratory can be qualified as an asymmetric partnership. The differences among partners

(e.g. size, resources) can lead to difficulties, such as a lack of trust between partners (Sarkar

et al. 2001), a delicate approach to development (Smith and Barclay 1997) or conflicts over

how to share the results (Das and Teng 2001). In addition, the need for heterogeneity among the partners pushed the management of MINATEC IDEAs Laboratory to include organisations from different sectors. ${ }^{2}$ This express decision, instituted at the origin of the partnership, aimed to ensure that the innovations would be situated in different sectors (e.g. research, optics, sport, telecommunication), which might stimulate the innovation process through sharing, making experience and expertise available and creating common synergies (through joint projects). In this sense, MINATEC IDEAs Laboratory counts cross-fertilisation as a major asset in its activity, re-enforced by a lack of competition between partners.

\footnotetext{
2 A direct industrial competitor of one of the partners can apply to enter though. Admission requires a unanimous vote by the representatives of the partners who sit on the management committee.
} 
The partnership also is legally coordinated by contracts among the different partners. These contractual agreements determine the methods of participation and distinguish three status levels: main partners, partners-projects and occasional partners. Main partners are all part of the management committee (CODIR) and have rights to veto admittance of new partners or enlarge the circle of main partners. Partner-projects have the same rights as the main partners but only for a specific project. Finally, occasional partners are admitted for precise, short-term missions. Thus this partnership enables partners to share the risks and costs involved in each project. Finally, occasional partners are admitted into MINATEC IDEAs Laboratory for a precise, short term mission, such as when Ecole Nationale Supérieure en Création Industrielle helped the laboratory set up design workshops in 2008. Strategic decisions for the partnership are made by the executive authority, namely, the management committee. It determines and validates future research directions and partners; that is, the laboratory is managed not by one partner in particular but collectively, which differentiates it from other structures (not partnerships), such as Medialab at the Massachusetts Institute of Technology, Interuniversity Microelectronics Centre (IMEC), ILab or the California Institute for Telecommunications and Information Technology (Cal(it) $\left.)^{2}\right)$. We also distinguish MINATEC IDEAs Laboratory from internal R\&D structures in various companies, such as Orange Lab (Orange), e lab (Bouygues), Philips Home Lab (Philips), Cre@team (EDF), the Palo Alto research center (Xerox Corporation) or Sony CSL (Sony). In effect, MINATEC IDEAs Laboratory represents a common structure linking companies and universities.

Organised in project modes, research within the partnership relies on different disciplines, whether in social sciences (sociology, anthropology, ergonomics, economics) or engineering (programming, engineering). the partnership often focuses on large domains that encompass various elements and services, such as the automobile sector, health, 
telecommunications, textiles or leisure. The specific project partnerships tend to be relatively

small and are managed by a project manager who answers directly to the management

committee. As we show in Table 2, the three projects we investigate-MagicBall, Map Mobile and Interfaces Visuelles-evolved within the same structure but also vary in their length, number of participating partners, objectives pursued and technologies used.

Table 2. Nature of focal exploratory projects

\begin{tabular}{|c|c|c|c|c|}
\hline \multirow{2}{*}{\multicolumn{2}{|c|}{$\begin{array}{c}\text { Characteristics } \\
\text { Reception structure }\end{array}$}} & Magicball & Map Mobile & $\begin{array}{l}\text { Interfaces } \\
\text { Visuelles }\end{array}$ \\
\hline & & \multicolumn{3}{|c|}{ MINATEC IDEAs Laboratory } \\
\hline & Maturity of partnership & \multicolumn{2}{|c|}{ Creation } & Maturity \\
\hline \multirow{7}{*}{$\frac{\bar{d}}{\mathscr{0}}$} & Expected results & $\begin{array}{l}\text { Models, studies of } \\
\text { usage }\end{array}$ & $\begin{array}{l}\text { Models, studies of } \\
\text { usage }\end{array}$ & Concepts, models \\
\hline & Number of partners & 6 & 4 & 9 \\
\hline & Basic technology & Accelerometer & Accelerometer & $\begin{array}{l}\text { Photochromic } \\
\text { glasses }\end{array}$ \\
\hline & Length of project & 2 years & 3 months & 3 years \\
\hline & $\begin{array}{c}\text { Heterogeneity of core } \\
\text { professions }\end{array}$ & Similar & Similar & Heterogeneous \\
\hline & $\begin{array}{c}\text { Interest of partners in the } \\
\text { project }\end{array}$ & Strong & Strong & Medium \\
\hline & $\begin{array}{c}\text { Partner providing } \\
\text { technology }\end{array}$ & \multicolumn{2}{|c|}{ CEA } & Essilor \\
\hline \multirow{4}{*}{ 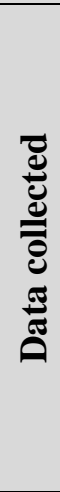 } & Number of interviews & 6 & 4 & 10 \\
\hline & People interviewed & $\begin{array}{c}\text { Prescribers of } \\
\text { project (1), legally } \\
\text { responsible members } \\
(5)\end{array}$ & $\begin{array}{l}\text { Prescribers of } \\
\text { project (1), legally } \\
\text { responsible } \\
\text { members (3) }\end{array}$ & $\begin{array}{l}\text { Prescribers of } \\
\text { project (1), legally } \\
\text { responsible } \\
\text { members }(8)\end{array}$ \\
\hline & Internal data & \multicolumn{3}{|c|}{$\begin{array}{l}\text { Participation contracts, project specifications, meeting minutes, } \\
\text { summary of activity }\end{array}$} \\
\hline & External data & \multicolumn{3}{|c|}{ Internet sites, specialised and general press articles } \\
\hline
\end{tabular}

The MagicBall and Map Mobile projects were initiated prior to the official start of the partnership (2002 and 2003), then continued after its creation. They use similar technologies and have parallel objectives (virtual displacement in space). The MagicBall project aimed to construct a prototype of a 3D mouse that could facilitate navigation across three-dimensional images. Its principle was based on intuitive gestures that would make it possible to move in 
virtual space. The partners all participated in achieving the prototype; several applications were envisaged and tested, including a skill-based navigation game using multimedia data (e.g. IGN@ maps).

Map Mobile launched in 2003, with the initiative of the founder partners (CEA, ST Microelectronics, France Telecom and Hewlett-Packard). It proposed a system for interactive localization inside and outside buildings. The project lasted three months, between the definition of the concept in spring 2003 and the construction of the first functional prototype.

Finally, the Interfaces Visuelles project started in 2006 at the initiative of the Essilor company, followed by the participation of all the partners (CEA, France Telecom, EDF, UPMF, U3, Teamlog, Rossignol and a confidential partner). The objective was to define concepts based on elements in personal spheres, using emerging technologies that enabled new visual interactions. This project lasted three years (2006-2008). We consider these project details carefully to analyse the dimensions that influence distribution choices.

\section{Heterogeneous forms of distribution}

To describe the three focal projects carried out in the MINATEC IDEAs Laboratory, we first consider the question of incentives, then move to the results.

\section{Result distribution as an incentive}

The result distribution methods for the three projects were specified in the contracts and referred to two alternative types of results. First, ideas and knowledge produced in the partnership could be integrated and reused by all partners except two: a (main) partner that could not access the knowledge and ideas before it officially entered into the partnership (i.e. without specific agreement), and an occasional partner, which only had access to the ideas and knowledge produced in the project on which it was is working, without any right of access to other projects' results. Second, the projects could result in industrial property with a patent. As a partnership, MINATEC IDEAs Laboratory chose to adopt a co-property 
regulation implying the distribution of 'The rights to equal shares of the invention, whatever the means that are implemented, and rights to the resulting Patent will belong to each party in equal shares' (standard participation contract, 2004, Article 3: Coproperty).

Furthermore, the distribution of the results depends on whether the new knowledge belongs to one of the partners or all partners. In the former situation, each party can exploit its own results and/or intellectual property, acquired or achieved during the execution of the contract, without providing financial returns to other parties. In the latter situation, all parties can exploit the results without having to compensate other parties. The results obtained in the three projects thus differ in nature, though all of them provided a concept definition. Usability testing was performed for MagicBall and Interfaces Visuelles. Others types of results also emerged, as we describe in Table 3.

Table 3. Results distributed in each project

\begin{tabular}{|c|c|c|c|}
\hline & MagicBall & Map Mobile & Interfaces Visuelles \\
\hline $\begin{array}{c}\text { Basic } \\
\text { results }\end{array}$ & $\begin{array}{l}\text { Concept definition } \\
\text { Working prototype } \\
\text { Usability testing }\end{array}$ & $\begin{array}{l}\text { Concept definition } \\
\text { Working prototype }\end{array}$ & $\begin{array}{c}\text { Concept definition } \\
\text { Concept testing } \\
\text { Working prototypes } \\
\text { Usability testing } \\
\text { Commercial agreement }\end{array}$ \\
\hline $\begin{array}{l}\text { Refined } \\
\text { results }\end{array}$ & $\begin{array}{c}\text { Usability scenario } \\
\text { Numeric maps } \\
\text { Development of micro- } \\
\text { accelerometer (MEMS) }\end{array}$ & $\begin{array}{l}\text { Possibility of WiFi } \\
\text { triangulation } \\
\text { Development of } 3 \mathrm{D} \\
\text { magnetometer }\end{array}$ & $\begin{array}{c}\text { Interactive make-up box } \\
\text { Semi-immersive glasses } \\
\text { Liquid Crystal Shutter } \\
\text { Mobile hypertext } \\
\text { technology }\end{array}$ \\
\hline
\end{tabular}

The distributions of these results also differ, as we describe next.

Choosing between equitable and egalitarian distribution

For the MagicBall and Map Mobile projects, the partnership opted for egalitarian distribution. The inventions originating from these partnership activities thus were the equally shared property of the parties that had invested in the project. All these partners were owners of the inventions created, and requests for patents were registered, with shared costs and equal shares. For these projects, the partnership was still in the process of determining its 
structure, and these two projects were its first collective creations. The partners represented relatively closely linked core professions (i.e. embedded microelectronics and telecommunications) and had similar interests. In turn, they appeared satisfied with the results obtained and validated the choice of an egalitarian distribution.

\footnotetext{
I found it a very good thing. That's to say that there was a part with a common core, where we shared the industrial property. And then, at a certain moment, there was concrete material, consisting of models and returns on the experiences gained in the experimenting which each company could make use of. Therefore, if there were patents to be registered for the Lab, they would be just basic elements in the sector, [and] after that each company could work on his own part with things that were quite elear (Map Mobile, project leader).
}

The two projects also included the same partners, so the interviews illustrate a collective work situation and considerable implications across both projects. The choice of an egalitarian distribution also might be justified because the partners represent different markets and thus would not compete as the technology develops.
The means adapted to situations in which the partners learn to work together and in which the different professions encounter one another (sociologists, engineers, etc.) and different markets (Magicball, manager of legal department).

The dependence of the partners on the technologies proposed by the CEA also motivated the choice of an egalitarian distribution. The CEA actually provides most of the technology used in the three projects, which leaves the other partners with relatively limited margins for manoeuvring with regard to the results.

The only partner that cannot leave is the CEA. We can try it: we can remove any one of them and the system still survives. I think that if we removed the CEA, the system would survive but there wouldn't be the same orientation. From this point of view, the 
other partners have a limited margin for manoeuvring with regard to the results obtained (Magicball, manager of legal department).

However, the Interfaces Visuelles project featured an evolution in the means of distribution. This case included many partners - nine at the outset. The partnership also was far more mature, in that it already had existed for five years and was not launching its first project. We thus observed an effect of experience. The participating partners had grown accustomed to working together, and the operational team was stable, in both its composition and its organisation. Unlike the MagicBall and Map Mobile projects, the partners opted for an equitable distribution of the results, motivated by their recognition that the fields of application did not involve every partner. The respondents we interviewed expressed only an average level of satisfaction though, because the results obtained were below the level they had hoped for.

\footnotetext{
Isaw the short film on the visual interface models, it was very nice, it was sold quite well, it was well done, but in the end, if we measure the difference between our intentions in the beginning and the results, there was quite a flagrant gap. We have progressed on interesting concepts, but in its current state, it still isn't as prolific as it could do (Interfaces Visuelles, manager of legal department).
}

Thus for Magic Ball and Map Mobile, the distribution sharing method is egalitarian, because that approach offers more advantages than limitations. Nor did the distribution mode change over the course of the projects. Several factors may explain this stability in distribution mode: The projects were initiated during the creation of the overall partnership, which ensured strong involvement, and the partners' businesses were closely related to the topics addressed in the project. Furthermore, the patent-protected technology already existed and was provided by one partner. Prototyping was facilitated, because the short-term projects 
only entailed technology combinations, and there was just one project manager for each project.

For Interfaces Visuelles though, an equitable distribution may offer more advantages. The expectations varied by partners, involving new usages, concepts and models. These different expectations affected how the partners regarded the implications of the project outcomes. Compared with its potential (value created, financial aspects, concept used), the partners reconsidered its actual implications during the project and identified two main difficulties that appeared to be caused by the choice of an equitable division. First, the project was relatively unconnected with the professions and markets that each partner represented. This difficulty challenged the very significance of the project for each of the partners, which meant that perceived benefits strongly influenced their investments during and after the project. Second, it became a challenge to establish effective performance metrics. Some interviewees specifically evoked the difficulty of establishing performance indicators for exploratory projects in which not all the partners had an evident interest. Without performance metrics, it was more difficult for some partners to identify and quantify results that could be relevant for their respective activities.

In brief, several factors likely explain the change from egalitarian to equitable distribution modes: the inclusion of new partners whose businesses differ, a long-term project timeline (e.g. more than three years), a complex project (e.g. combination of different technologies in a broader concept compared with MagicBall and Map Mobile), a larger project team and several project managers. Table 4 contains a summary of the main advantages and limitations of each distribution method.

Table 4. Main advantages and limitations of distribution choice

\begin{tabular}{|c|c|c|c|}
\hline & MagicBall & Map Mobile & Interfaces Visuelles \\
\hline $\begin{array}{c}\text { Type of } \\
\text { distribution }\end{array}$ & \multicolumn{2}{|c|}{ Egalitarian } & Equitable \\
\hline
\end{tabular}




\begin{tabular}{|c|c|c|}
\hline $\begin{array}{c}\text { Main } \\
\text { advantages }\end{array}$ & $\begin{array}{l}\text { - Collective interest in the projects. } \\
\text { level, which helps ensure partners' } \\
\text { motivation and involvement. } \\
\text { - Institutional trust exists, and the } \\
\text { distribution mode allows the persistence } \\
\text { of such trust. } \\
\text { - Both projects initiated at the beginning } \\
\text { of the partnership, so the boundaries } \\
\text { were unknown. It took less time and was } \\
\text { easier to establish an equal distribution } \\
\text { agreement. }\end{array}$ & $\begin{array}{l}\text { Each partner conserves and } \\
\text { protects its specific assets } \\
\text { (e.g. patents, expertise, } \\
\text { skills). } \\
\text { - One partner (i.e. CEA) } \\
\text { provides the main technical } \\
\text { contribution. } \\
\text { The contributions of each } \\
\text { partner were clearly } \\
\text { identified at the beginning of } \\
\text { the project, which reduced } \\
\text { the probability of conflict } \\
\text { about results appropriation. } \\
\end{array}$ \\
\hline $\begin{array}{c}\text { Main } \\
\text { limitations }\end{array}$ & $\begin{array}{l}\text { Favours opportunistic behaviours; in } \\
\text { these examples, two partners captured } \\
\text { part of the technology for their own } \\
\text { projects and quickly left the partnership. }\end{array}$ & $\begin{array}{l}\text { - Any reorientation involves a } \\
\text { renegotiation of resources } \\
\text { needed and results } \\
\text { distributed. It was difficult to } \\
\text { change the strategic } \\
\text { orientation chosen at the } \\
\text { beginning of the project. }\end{array}$ \\
\hline
\end{tabular}

In summary, the MINATEC IDEAs Laboratory structure opted ex ante for an egalitarian distribution, regardless of the characteristics of the projects and partners. However, the Interfaces Visuelles project—which contained more partners than the other two projects, occurred when the partnership was no longer in a creation phase and entailed more heterogeneity in the core businesses - necessitated a change to the method of distribution. Moreover, the implications and interests of the partners differed greatly across the organisations. These multiple differences prompted the choice of equitable distribution; in particular, the resources and skills provided by each party were too heterogeneous to envisage a different type of sharing.

\section{Discussion}

Literature on exploratory partnerships remains relatively evasive about the best methods to distribute results. Beyond their high degrees of uncertainty and risk, these partnerships can struggle because the methods of distribution are difficult to set up ex ante, especially when the results of the alliance (e.g. identifying a new opportunity, the emergence of new business 
opportunities) and its quasi-rents ${ }^{3}$ cannot be calculated in advance. However, in these situations, it is possible:

- To forecast, before the alliance, how property rights, connected with emerging opportunities during the alliance, should be distributed.

- To determine the percentage of remuneration and envisage a specific clause to address unexpected factors. For example, in a collaboration with equivalent proportions (5050), members can create a reserve for contingencies in equal proportions, used in the case of an unexpected risk.

Therefore, even though result distributions should not be rigidly defined in an alliance proposition (which may have a counter-incentive effect on partners), the principles of collaboration can and should be discussed beforehand (Segrestin 2006).

Types of results

In exploratory partnerships, two main types of results will emerge and need to be distributed:

- Property and rights to patents, drawings or models, which generally should not be distributed to a single actor, to avoid tests of strength.

- Financial results generated by a market launch, for which, unlike other types of inter-organisational relations such as franchise networks, innovation partners rarely seem to use quasi-rents (De Guilloux et al. 2004).

\section{Incentive nature}

The distribution of quasi-rents is often a principal motive for development partnerships - as well as a principle cause of arguments to decide on the appropriate distribution (equitable or egalitarian). There is no universal rule for the distribution of value,

\footnotetext{
${ }^{3}$ Quasi-rents derive from cooperation and refer to the surplus profit made by members because of their partnership. Quasi-rent is therefore the spread between two profits: that which would have been earned without the alliance and that made due to it.
} 
especially when resources and skills are difficult to measure (Das and Teng 2000). The contribution of each member is complicated to determine in an innovation project, which requires vast intangible resources (e.g. technique knowledge, market information) that cannot be measured in an objective way (cf. financial investment) and are based on the arbitrage of each project. The partners can assess the financial contributions of each member but cannot objectively determine the value of intangible contributions, such as one partner's brand image (Urban and Vendemini 1994). Yet despite these challenges and regardless of the uncertainty inherent to partnerships and innovation projects, our research shows that it is better to define ex ante the rules for the distribution of results, without setting them too rigidly (i.e. Interfaces Visuelles case study). They must be redefined according to advances in the project and precise identifications of necessary resources and skills. Causes for renegotiation might include a weak contribution by certain partners or the advent of an alternative technology.

\section{Equitable versus egalitarian distribution}

At the beginning of a partnership, partners determine what each will obtain at the end of the project. In line with Lucas and Piron's (1998, p. 5) summary of the European Tactical Missiles Alliance between Matra and Bae Dynamics, we find that equity seems to be the only means of creating a certain legitimacy when allocating resources. This question is often wrongly reduced to a problem of 'just returns', involving the financial proportionality between the contribution in market terms and the contribution in terms of tasks. For the prescribers or negotiators of the alliance, the question of just returns can be answered, once and for all, prior to the conclusion of the alliance, in financial terms. However equity remains a question during the structuring of the project, and beyond.

Thus the relation between contributions and the compensation of members and the influence of this relation on members' perception of distributive justice is critical. Yet equitable distribution is difficult to establish. It depends on norms of justice, which vary from 
one group to another and across cultures. Equity does not always appear preferable to equality; rather, results should be distributed according to outputs, such that the distribution encourages and recompenses those members that have invested the most.

Moreover, when a company makes an investment in an exploratory activity that comes close to the activities of other partners, the company should be more inclined to assign its rights (Vassolo, Anand, and Folta 2004). By extension, our research indicates that the closer the exploratory results are to a company's core activities, the more reticent the company is to share its results with partners who are only slightly involved.

\section{Conclusion}

This article has focused on different types of results and their associated methods of distribution. These elements are inherent to partnership relations and particularly difficult to implement in an exploratory partnership, which is by nature risky and uncertain. Two main contributions emerge from this study:

- The choice of distribution methods depends on three principal structural dimensions. For Map Mobile and MagicBall, the methods were defined from the point of creation of the partnership. The number of partners was limited, and the core professions were close and even complementary. For Interfaces Visuelles, the broader partnership already was well established when the project was launched, and there were many stable partners (i.e. few new members and few members leaving). According to these findings, equalitarian distribution seems preferable when a partnership is in the preliminary stages, there are few partners and the fields of activity are close. An equitable distribution instead is preferred when the exploratory partnership includes a large number of partners, and their core professions are very different.

- The methods diverge according to the partners' behaviours. The level of contributions and interest shown in the project influences the distribution methods chosen. A 
partner that can directly re-appropriate the results of the exploration for its own activities will tend to prefer equitable distribution and consider it, in this case, more just.

Along with these contributions, the current study has several limitations. For example, with regard to the characteristics of the projects studied, this research has focused on an asymmetrical partnership containing partners with varied profiles. It would be interesting to study exploratory partnerships between competitive companies, to analyse the possible repercussions of these similarities on result distributions. In such a context, the partners continue to compete (Nalebuff and Brandenburger 1996), and the partnership creates a high risk of opportunism and conflict. In addition, we analysed only one incentive mechanism, namely, the methods used to distribute the results. A simultaneous study of several motivating mechanisms could reveal other dimensions that also influence the type of distribution. For example, the extent of the contract or the degree of confidence among partners likely influences the choice of distribution methods. Intuitively, we might imagine that when partners trust each other more, the risks of opportunism and quasi-rents decline. Thus, partners should be less reticent about opting for an egalitarian distribution, even if they have heterogeneous levels of commitment.

\section{References}

Adams J.S. 1963. Toward an understanding of inequity. Journal of Abnormal and Social Psychology 67: 422-436.

Anderson E., and Weitz B. 1992. The use of pledges to build and sustain commitment in distribution channels. Journal of Marketing Research 29: 18-34.

Arino A., and De La Torre J. 1998. Learning from failure: Towards an evolutionary model of cooperative venture. Organization Science 9(3): 306-325. 
Bhaskaran S., and Krishnan V. 2009. Effort, revenue and cost sharing in collaborative new product development. Management Science 55 (7): 1152-1169.

Bierly P., and Gallagher S. 2007. Explaining alliance partner selection: fit, trust and strategic expediency. Long Range Planning 40 (2): 134-153.

\section{Blanchot F. 2006. Alliances et performances: un essai de synthèse. Cahier de Recherche} CREPA DRM, $\mathrm{n}^{\circ} 1$.

Borys B., and Jemison D.B. 1989. Hybrid arrangements as strategic alliances: Theoretical issues in organizational combinations. Academy of Management Review 14: 234-249.

Bower J.L., and Christensen C.M. 1995. Disruptive technologies: Catching the wave. Harvard Business Review 73(1): 43-53.

Brickley, J.A., Smith, C.W., and Zimmerman, J.L. 1997. Managerial Economics and Organizational Architecture. New York: Irwin/McGraw-Hill.

Catelin, C. 2002. Architecture organisationnelle et politique d'investissement: une illustration à travers une double méthodologie empirique. $15^{e ̀ m e}$ Conférence Internationale ESCP EAP, Paris.

Chanal, V., and Mothe, C. 2005. Comment concilier innovation d'exploitation et innovation d'exploration: une étude de cas dans le secteur automobile. Revue Française de Gestion 31: 173-191.

Chesbrough, H. 2003. Open innovation: how companies actually do it. Harvard Business Review 81(7): 12-14.

Cooper, R.G. 1999. The invisible success factors in product innovation. Journal of Product Innovation Management 16 (2): 115-133.

Das, T.K., and Teng, B.S. 2000. Instabilities of strategic alliances: An internal tensions perspective. Organization Science 11: 77-101. 
Das, T.K., and Teng, B.S. 2001. Trust, control and risk in strategic alliances: an integrated framework. Organization Studies 22 (2): 251- 283.

De Guilloux, V., Gauzente, C., Kalika, M., and Dubost, N. 2004. How France's potential franchisees reach their decisions: a comparison with franchiser's perceptions. Journal of Small Business Management 42 (2): 218-224.

Dhanaraj, C., and Parkhe, A. 2006. Orchestrating innovation networks. Academy of Management Review 31(3): 659-662.

Doz, Y.L., and Hamel, G. 1998. Alliance Advantage: The Art of Creating Value Through Partnering. Boston: Harvard Business School Press.

Eisenhardt, K.M. (1989). Building theories from case study research. Academy of Management Review 14 (4): 532-550.

Emden, Z., Calantone, R.J., and Droge, C. 2006. Collaborating for new product development: selecting the partner with maximum potential to create value. Journal of Product Innovation Management 23 (4): 330-341.

Foss, N.J. 2003. Selective intervention and internal hybrids: Interpreting and learning from the rise and decline of the Oticon Spaghetti Organisation. Organisation Science 14(3): 331349.

Gillier, T., Piat, G., Roussel, B. and Truchot, P. 2010. Managing innovation fields in a crossindustry exploratory partnership with C-K Design Theory. Journal of Product Innovation Management 27: 883-896.

Goes, J.B., and Park, H.S. 1997. Interorganizational links and innovation: The case of hospital services. Academy of Management Journal 40 (3): 673-696.

Griffin, A., and Page, A. 1993. An interim report on measuring product development success and failure. Journal of Product Innovation Management 10 (4): 291-308. 
Inkpen, A., and Beamish, P.W. 1997. Knowledge, bargaining power and international joint venture instability. Academy of Management Review 22 (1): 177-202.

Jap, S.D. 2001. Pie sharing in complex collaboration contexts. Journal of Marketing Research 38 (1): 1547-7193.

Johnson, G., Scholes, K., Whittington, R., and Fréry, F. 2008. Stratégique, 8th ed. Person Education.

Kabanoff, B. 1991. Equity, equality, power and conflict. Academy of Management Review 16 (2): 416-441.

Kang, K.H.; and Kang J. 2010. Does partner type matter in R\&D collaboration for product innovation? Technology Analysis \& Strategic Management, 22(8):945-959.

Karlsson, C. 1997. Product development, innovation networks, infrastructure and agglomeration economies. Annals of Regional Science 31: 235-258.

Kogut, B. 1989. The stability of joint ventures: Reciprocity and competitive rivalry. Journal of Industrial Economics 38: 183-198.

Kumar, R., and Nti, K. 1998. Differential learning and interaction in alliance dynamics: A process and outcome discrepancy model. Organization Science 9 (3): 356-365.

Larson, A. 1992. Network dyads in entrepreneurial settings: \ study of the governance exchange of relationships. Administrative Science Quarterly 37 (1): 76-104.

Larsson, R., Bengtsson, L., Henriksson, K., and Sparks, J. 1998. The interorganizational learning dilemma: collective knowledge development in strategic alliances. Organization Science 9 (3): 285-305.

Leiblein, M.J., and Madsen, T. 2009. Unbundling competitive heterogeneity: incentive structures and capability influences on technological innovation. Strategic Management Journal 30 (7): 711-735. 
Le Masson, P., Weil, B., and Hatchuel, A. 2006. Les processus d'innovation: Conception innovante et croissance des entreprises. Hermès Science Publications.

Lucas, O., and Piron, P. 1998. La conception en Alliance intégrée. Le cas de l'alliance européenne des missiles tactiques. Séminaire Ressources Technologiques et Innovation, Ecole de Paris du Management.

Malik, K., and Wei, J. 2011. How external partnering enhances innovation: evidence from Chinese technology-based SMEs. Technology Analysis \& Strategic Management 23(4): 401-413.

McMillan, I., and McGrath, R.G. 2000. The Entrepreneurial Mindset: Strategies for Continuously Creating Opportunity in an Age of Uncertainty. Boston: Harvard Business School Press.

Miles, M.B., and Huberman, A.M. 2003. Analyse de données qualitatives: Recueil de nouvelles méthodes, 2d ed. Bruxelles: De Boeck.

Mohr, J., and Spekman, R. 1994. Characteristics of partnership success: Partnership attributes, communication behavior, and conflict resolution techniques. Strategic Management Journal 15 (2): 135-152.

Nalebuff, B., and Brandenburger, A. 1996. La co-opétition, une révolution dans la manière de jouer concurrence et coopération. Village Mondial.

Nelson, R.R., and Winter, S.G. 1982. An Evolutionary Theory of Economic Change. Boston: Harvard University Press.

Nooteboom, B., van Haverbekem, W.P.M., Duijsters, G.M., Gilsing, V.A., and Oord, A. 2007. Optimal cognitive distance and absorptive capacity. Research Policy 36: 1016-1034.

Powell, W.W. 1987. Hybrid organizational arrangements: New form or transitional development? California Management Review 30(1): 67-87. 
Powell, W.W., Koput, K.W., and Smith-Doerr, L. 1996. Interorganizational collaboration and the locus of innovation: Networks of learning in biotechnology. Administrative Science Quarterly 41: 116-145.

Quélin, B. 1996. Coopération inter-entreprises et création de resources. In Coopération entre tes entreprises et Organisation Industrielle, J. L. Ravix, ed. CNRS Editions, 111 139.

Rothaermel, F.T., and Deeds, D.L. 2004. Exploration and exploitation alliances in biotechnology: A system of new product development. Strategic Management Journal 25 (3): 201-221.

Sakakibara, M. 1997. Heterogeneity of firm capabilities and cooperative research and development: An empirical examination of motives. Strategic Management Journal 18: 143-164.

Sarkar, M.B., Echambadi, R., Cavugsil, S.T., and Aulakh, P.S. 2001. The influence of complementarity, compatibility, and relationship capital on alliance performance. Journal Of the Academy of Marketing Science 29 (4): 358373.

Segrestin, B. 2006. Innovation et coopération interentreprises. Comment gérer les partenariats d'exploration? Paris: CNRS Editions.

Smith, B.J., and Barclay, D.W. 1999. Selling partner relationships: The role of interdependence and relative influence. Journal of Personal Selling \& Sales Management 61(4): $21-40$.

Todeva, E., and Knoke, D. 2005. Strategic alliances \& models of collaboration. Journal of Management Decisions 43 (1): 123-148.

Urban, S., and Vendemini, S. 1994. Alliances stratégiques coopératives européennes. Bruxelles: De Boeck Université. 
Vassolo, R.S., Anand, J., and Folta, T.B. 2004. Non-additivity in portfolios of exploration activities: A real options-based analysis of equity alliances in biotechnology. Strategic Management Journal 25 (11): 1045-1061.

Yap, C.M., and Souder, W.E. 1994. Factors influencing new product success and failure in small entrepreneurial high-technology electronics firms. Journal of Product Innovation Management 11: 418-432.

Yin, R.K. 2003. Case Study Research. Design and Methods. Sage Publications, 200 p. 